\title{
Re-engineering land administration systems for sustainable development - from rhetoric to reality
}

\author{
Ian P. Williamson ${ }^{1,2}$ \\ ${ }^{1}$ Visiting Professor (October 2000 - February 2001), Department of Geodesy, Delft \\ University of Technology, The Netherlands \\ ${ }^{2}$ Department of Geomatics, The University of Melbourne, Victoria 3010, Australia (Tel: \\ +61-3-8344 4431; Fax: +61-3-9347 4128; e-mail: ianpw@ unimelb.edu.au, URL: \\ www.geom.unimelb.edu.au/people/ipw.html)
}

KEYWORDS: land administration, cadastre, sustainable development, re-engineering

\begin{abstract}
Current land administration systems are the product of 19th century economic and land market paradigms and have failed to properly support sustainable development. The need for urgent reform is accepted, but the way forward unclear in many jurisdictions. This paper will discuss current international initiatives and research to develop a new land administration vision to promote sustainable development. Within this context, this paper describes the changing humankind to land relationship, identifies some of the growing environmental pressures facing modern society and the need for sustainable development, explores the evolving role of land administration in society and highlights the need for land administration systems to play a more proactive role in supporting sustainable development objectives. The process to re-engineer land administrations is briefly reviewed. The paper then highlights the development of a national land administration vision and strategy. In proposing strategies the paper draws on international trends and experiences such as highlighted in the recent United Nations - International Federation of Surveyors Declaration on Land Administration for Sustainable Development.
\end{abstract}




\section{$\{$ heading 1$\}$ Introduction}

Land, and the interaction of human societies with it, result in many economic, social, political and environmental concerns. The dialogue between these competing and overlapping concerns requires a land administration system that is able to support the ever changing relationship between humankind and land, to facilitate complex decision making and to support the implementation of those decisions. Therefore, appropriate and effective land administration is of crucial importance for sustainable development.

In recent decades the global drivers of sustainable development, environmental sustainability, globalisation, urbanisation, economic reform and technology have influenced the development of the different land administration polices and models adopted by governments. These models and concepts can only be developed with a clear understanding of current land administration issues and trends. By its very nature, land administration focuses on land tenure and cadastral (land parcel related) issues. The land administration perspective includes understanding the changing humankind-land relationship, private and public property rights, land tenure issues such as native title, institutional and administrative issues such as the relationship between infrastructures and the business systems they support, the design and role of spatial data infrastructures (SDI), and technical issues such as those concerned with the use of the World Wide Web (WWW).

Land administration trends have followed a course mapped by dynamic changes in societies and their increasingly complex attitudes to land as personal security, wealth, as an expendable commodity, as a scarce community resource, in support of environmental survival and sustainable development [Ting \& Williamson, 1999]. 
Within this context, this paper describes the changing humankind to land relationship, identifies some of the growing environmental pressures facing modern society and the need for sustainable development, explores the evolving role of land administration in society and highlights the need for land administration systems to play a more proactive role in supporting sustainable development objectives. The process to re-engineer land administration systems is briefly reviewed. The paper then highlights the development of a national land administration vision and strategy.

\section{\{heading 1\} The changing humankind to land relationship}

The relationship between humankind and land in almost every society is dynamic, albeit the relationship varies for almost every situation [Ting \& Williamson, 1999]. This continual change can be seen in the context of "Western" land tenure systems in Figure 1.

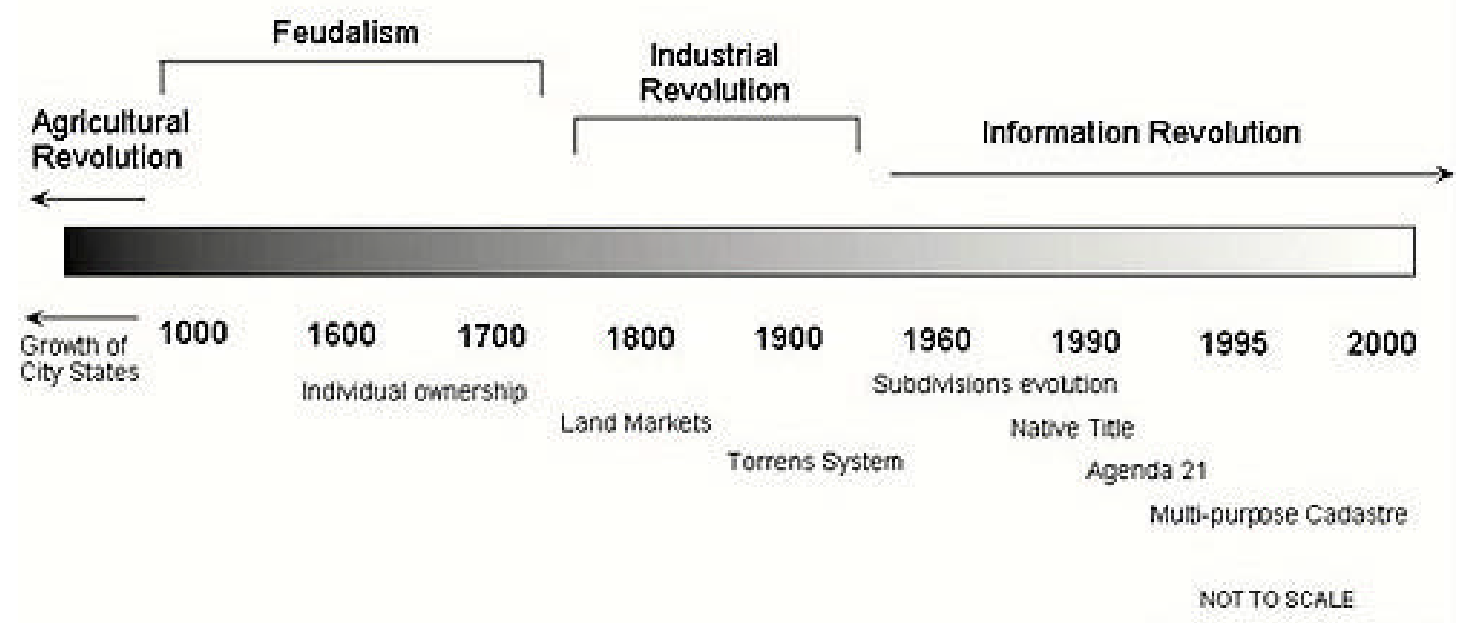

Figure 1: A Western view of the changing humankind to land relationship [Ting \& Williamson, 1999]

A review of the dynamic humankind-land relationship [Ting \& Williamson, 1999] shows that in a western context, it may be classified into four broad phases: 
- Human settlement during the agricultural revolution through to the feudal system, which tied human beings to land in a physical way. Land was the primary symbol and source of wealth. In this phase, the cadastral system's role was to publicly record ownership as well as for fiscal purposes.

- The Industrial Revolution began a process of breaking that strong physical tie to land by turning land into more of a commodity, albeit the most valuable commodity and primary source of capital. In many western countries, the mobility of people and the rise of capital and commodification of land brought by the Industrial Revolution, gave birth to major legal and institutional changes. This environment gave birth to land markets and so cadastre took on another focus - a tool to support land transfer and land markets. The Torrens system of land titling is a good example of the institutional and legal responses to the burgeoning of land markets in the 19th Century.

- The post-World War II reconstruction and the population boom saw an awareness of land as a scarce resource that was not sufficient for the needs of a growing world population which was becoming more mobile. With this came an interest in planning, particularly urban and regional planning. Planning in turn created another application for the cadastre.

- The 1980s have seen a different twist in the concern for the scarcity of land. The focus has turned to wider issues of environmental degradation and sustainable development, as well as social equity. All of these issues have the probable effect of tempering short-term economic imperatives. Planning issues have widened to include more community interests and deepened to address more detailed issues of land use. This has created a growing need for more complex information about land and land use. The impact of these has been manifested in the desire for multi-purpose cadastres.

The land administration response to these changing phases is shown diagrammatically in Figure 2 . 


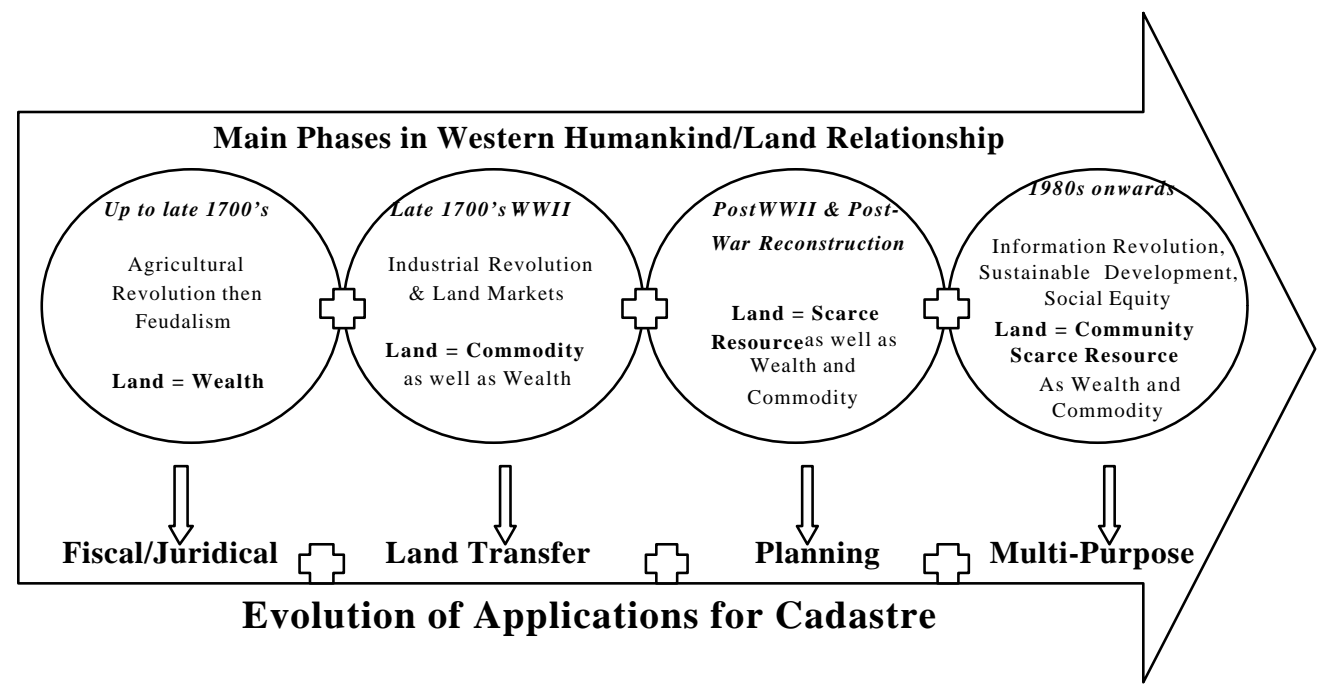

Figure 2: Evolution of applications for Casdastre [Ting \& Williamson, 1999]

Many developed countries are in the course of making the transition from the third to the fourth phases, while many developing countries are experiencing change across all four phases. Apart from examining local, state or national structures and their associated legal, institutional, economic and social frameworks, the current era requires that nations take into consideration these global drivers.

However for most countries, land administration reform is not that simple. On the one hand the relationship of humankind to land varies across a country from urban areas, with active land markets and often informal settlements, to both titled and non titled rural areas, to areas under traditional or indigenous rights with no land market, to areas under a range of different common property tenures. This then requires different land administration responses for these respective areas [Williamson, 2000]. This is further complicated since countries are at different stages of development thereby affecting the choice of the land administration response. As mentioned above neither of these situations is static; neither the different humankind to land relationships nor the stage of development of the country. So the response proposed today based on current 
requirements might not be appropriate for tomorrow since the requirements may be different.

In summary the key outcomes from this analysis are that the relationship of humankind to land in almost all societies is dynamic being influenced by these global drivers, and that this changing relationship results in a changing land administration response over time.

\section{\{heading 1$\}$ Environmental pressures}

The above analysis also shows that during the last twenty years there has been a trend towards tempering raw economic priorities with society's growing awareness and preparedness on environmental and social (eg, indigenous rights and issues concerned with women's access to land) priorities. Undoubtedly, the sharpest dialogue during this period is between the economic and environmental forces. People are both the problem and the solution.

In 1992, the historic UN conference in Rio de Janeiro (The Earth Summit) produced Agenda 21 [UN, 1992], which stated in its preamble that:

"Humanity stands at a defining moment in history. We are confronted with a perpetuation of disparities between and within nations, a worsening of poverty, hunger, ill health and illiteracy, and the continuing deterioration of the ecosystems on which we depend for our well being. However, integration of environment and development concerns and greater attention to them will lead to the fulfillment of basic needs, improved living standards for all, better protected and managed ecosystems and a safer, more prosperous future. No nation can achieve this on its own: but together we can - in a global partnership for sustainable development."

The world's population now stands at 6 billion. According to the United Nations Environment Program's (UNEP) 1999 statistics [United Nations, 1999]: 
- half of the world's population currently lives in urban areas and within thirty years this will increase to two-thirds;

- by 2025, two-thirds of the world's population will live in water-stressed conditions with irrigated agriculture accounting for 70-75 percent of fresh water use;

- human-induced degradation of the soil has already affected 20 percent of the world's drylands and puts the livelihoods of one billion people at risk;

- more than half of the world's population live within $60 \mathrm{~km}$ of the shoreline. One-third of those coastlines are already damaged by population stress and infrastructure (or lack thereof);

- global emissions of $\mathrm{CO}_{2}$ reached a new high of nearly 23.9 billion tonnes in 1996 nearly four times the 1950 total;

- in 1995, 25 per cent of the world's 4,630 mammal species and 11 per cent of the 9,675 bird species were at significant risk of extinction; and

- average global per capita income has now passed USD 5,000 a year but more than 1 billion people still live on less than USD 1 per day.

Interweaved with these crises are matters of poverty and the north-south divide: a tenfold reduction in resource consumption in industrialised countries is a necessary long-term target if adequate resources are to be released for developing countries.

Ten years on and seven years after the launch of Agenda 21, the joint United Nations and International Federation of Surveyors Bathurst Declaration on Land Administration for Sustainable Development [UN-FIG, 1999; Williamson et al, 1999] found that the most serious problems facing the relationship between land and people included:

- degradation of land due to unsustainable land use practices;

- lack of land for suitable urban development;

- lack of security of tenure (which in many societies impacts most severely on women and children);

- inequitable access to land by indigenous peoples and minority groups;

- access to land by women; 
- increasing vulnerability to disaster;

- destruction of bio-diversity;

- lack of adequate planning and of effective land administration;

- tensions between environmental conservation and development; and

- impact of market forces on traditional economies and tenures.

As the UNEP statistics gravely emphasise, the tensions are sharpening between human behavior and their worsening impact on the environment. This has profound implications for the survival of future generations. It is this dynamic which starts to bring land administration and land management into closer and even overlapping proximity. If these systems do not respond and expand to meet the challenges of society's increasingly complex relationship with land, sustainable development will not move beyond rhetoric.

These tensions emphasise the need for complex and sophisticated decision-making which, in the context of economic reforms, means not only in government but the private sector and wider community. Civil society demands a place in the framework of decisionmaking. The WWW is just one example of the information revolution potential that exists to bring consultation and participation to a new level of effectiveness.

It is in this context that the next generation of land administration systems will have to be developed.

\section{$\{$ heading 1$\}$ Land administration trends}

Ten years ago, a study of the World Bank's projects [Williamson, 1991] saw a move away from sporadic physical infrastructure interventions to encompass broader infrastructure issues of greater impact for national economies and the productivity of cities. The major research topics identified in the then World Bank's Urban Development Division were:

- Municipal finance and management; 
- Urban infrastructure productivity and willingness to pay for urban services;

- Housing markets and housing policy;

- Housing finance institutions and policies;

- Land management; and

- Urban environment policy

The World Bank's Development Report 1989 [World Bank, 1989] recognised the importance of property rights as well as the lack of adequate systems in administering them:

"The legal recognition of property rights - that is, rights of exclusive use and control over particular resources - gives owners incentives to use resources efficiently. Without the right to exclude others from their land, farmers do not have an incentive to plow, sow, weed and harvest. Without land tenure, they have no incentive to invest in irrigation or other improvements that would repay the investment over time. Efficiency can be further served by making property rights transferable." (p. 86)

"In most countries real estate accounts for between half and three quarters of national wealth. If ownership is widely dispersed, tenure is secure, and title transfer is easy, real estate can be good collateral for nearly any type of lending. Unfortunately, these conditions are not always met in developing countries. Land distribution is often skewed, tenure (if any) insecure, and title transfer cumbersome. One key to a smoothly functioning system of land tenure is land registers supported by cadastral surveys. In many developing countries these are still woefully inadequate or missing altogether." (p. 87)

Over the last decade the focus of organisations such as the World Bank within land administration reform projects has been primarily on access to land, security of tenure and the operation of land markets. Simplisticly the focus has been on individual land owners, not usually on a wider land administration infrastructure unless as a response to this narrower objective. While these projects may have also considered environmental 
and sustainable development issues, the reality is that the focus has been primarily on the economic dimension of land administration reform. This view is confirmed by a review influenced by rural sector policies by Deininger \& Binswanger [1999] of:

“...the evolution of policy recommendations concerning rural land issues since the formulation of the World Bank's "Land Reform Policy Paper" in 1975. That paper set out three guiding principles: the desirability of owner-operated family farms; the need for markets to permit land to be transferred to more productive users; and the importance of egalitarian asset distribution. In the 25 years since that paper was published, these guiding principles have remained the same, but it is now recognised that communal tenure systems can be more cost-effective than formal title, that titling programs should be judged on their equity as well as their efficiency, that the potential of land rental markets has often been severely underestimated, that landsale markets enhance efficiency only if they are integrated into a broader effort developing rural factor markets, and that land reform is more likely to result in a reduction of poverty if it harnesses (rather than undermines) the operation of land markets and is implemented in a decentralized fashion. Achieving land policies that incorporate these elemsnts requires a cogent legal and institutional framework together with greater reliance on pilot programs to examione the applicability of interventions under local conditions."

The view is also confirmed by an overview of World Bank projects from an urban sector perspective by Galal \& Razzaz [2000] in a World Bank paper titled "Reforming land and real estate markets".

As is the case in many developed countries, the focus of most land administration reforms in World Bank projects has been on either documenting or improving the administration of private rights. To a large extent this is because of the complexity in addressing national land administration reform, and as such the focus has not been on the development of national integrated land administration policies and infrastructures which incorporate both private as well as public rights. These projects have tended to exclude tenures 
concerned with common property, state lands, forest lands and other forms of property such as water rights from land administration reform projects. This focus on administering only private rights within national land administration systems has restricted those land administration systems addressing sustainable development objectives in an integrated manner at a state or national level. This is not a criticism of these projects since the economic driver has a high priority in developing countries and that it is only in recent years that the environmental and sustainable development priorities have gained greater momentum.

On the other hand, proposals for a more integrated and national approach to land administration should not come as a surprise, especially for developing countries. The reality is that many of todays developed countries went through a period of development not dis-similar to many of todays developing countries. Australia, Canada, the USA and New Zealand are good cases in point. In the early years of their development national integrated land administration strategies were central to government policy. Australian states (they were then separate colonies) usually had large Departments of Lands which were responsible for integrated colony wide land administration policies for both private and public rights. These departments managed the development of comprehensive land administration infrastructures showing all private and government lands, including reserves, forests etc. In the intervening years the need for these large government departments reduced as the tenure pattern stabilised and was fully documented. It is only in the last decade or so that the importance of an integrated state or national strategy has again risen in part as a response to the information revolution but also due to the need to manage the land resource in a more integrated manner. Suffice to say that there is a very positive historical justification for an integrated approach to land administration systems in developing countries.

\section{\{heading 1$\}$ Bringing land administration and sustainable development closer together}


The relationship between land administration and sustainable development is not universally accepted and many would say in unproven. This situation is similar to that between land administration (and more particularly land titling of private rights) and the economic benefits of such initiatives two decades ago. Even though international instruments, such as Agenda 21, recognise the importance of property rights and land administration to some degree in supporting sustainable development, the relationship is not quantified. In general national environmental or natural resource management policies rarely mention "land", "land administration" or "property rights" (see for example the WWW site for Environment Australia http://www.environment.gov.au/). The World Bank's Discussion Draft titled “Toward an Environment Strategy for the World Bank Group", April 2000 [World Bank, 2000] makes some mention of the role of land and property rights, albeit very briefly. Surprisingly it appears to recognise that these are central aspects of any environmental management implementation strategy but does not identify the role of land administration in environmental strategies. Relevant sections in the draft highlight this recognition and include:

- “...opportunities to empower the poor are clearly linked to equity issues such as property rights."

- "Natural resource management issues vary...but there are some common concerns specifically related to property rights..."

- "Inequity in land ownership...jointly foster(s) inequity and unsustainable use.", and

- "...harness the role of markets...to promote sustainable environmental management and investment."

The UN-FIG Bathurst Declaration on Land Administration for Sustainable Development [UN-FIG, 1999; Williamson et al, 1999] which resulted from a Workshop and International Conference on Land tenure and Cadastral Infrastructures for Sustainable Development, did establish a strong linkage between land administration and sustainable development. Importantly this Declaration sets out evolving concepts and principles, which add to and build on a rich body of knowledge in land administration, and particularly cadastres, developed over more than half a century. This body of knowledge 
includes a wide range of journal articles, books, reports, statements, policies and declarations from international organisations such as the UN and the World Bank, from individual country governments, as well as from many individuals.

The Bathurst Declaration concluded that "most land administration systems today are not adequate to cope with the increasingly complex range of rights, restrictions and responsibilities in relation to land, which are influenced by such factors as water, indigenous land use, noise and pollution" and "governmental information systems will have to continue their present trend to become increasingly open and public ... and governments have an important role as umpire, moderator and purveyor". In short, land information and land administration systems need to be re-engineered and to evolve to face the increasing complexity of the humankind-land relationship. Since many existing land administration systems are still based on a relatively narrow land administration paradigm centred on land registration and cadastral surveying and mapping, a new paradigm is required.

The Declaration acknowledged that the changing humankind-land relationship and society's priorities would require changes in land administration systems:

- to play a role in facilitating and supporting the complex decision making that is integral to sustainable development;

- to embrace the inter-relationship between good governance, civil society and land administration for sustainable development, and the need for accountability and benchmarking/performance indicators;

- to undertake legal, institutional and technological reforms to fulfil the call for inclusive decision-making and a holistic approach to land, water and other resource allocation/preservation issues;

- to ensure an inter-disciplinary approach to land administration and therefore the responsibility of nations to address the need for appropriate human resource development; 
- to evolve beyond traditional cadastral paradigms to embrace fresh understanding of the relationship between land, property and rights and the need for initiatives like decision-support systems and spatial data infrastructures;

- to respond creatively to differing needs and desires for tenure systems that could deliver equity, whether to specific disadvantaged groups within or between nations;

- to be expanded in order to provide information for land market activities, for public and private land management and for customary and informal tenures, in order to support sustainable development;

- to the laws concerned with information in the land registration system which may need to be adapted to current technological developments, for instance, in order to facilitate electronic conveyancing;

- to the statutory survey requirements on the location of pegs, boundaries and parcels to be adapted to more flexible circumstances depending on the character of the information and the use of the information for different purposes; and

- to be re-engineered to accommodate other forms of information, which may not be parcel, based.

\section{\{heading 1$\}$ Re-engineering land administration systems}

Unfortunately much change in the broad land administration area in many countries focuses on technology and does not take a broad view of land administration reform as identified by Ting \& Williamson [1999] and as discussed above. It is useful to consider three related perspectives in implementing change in land administration. First is an appreciation of the global drivers for change, which were mentioned previously. Next is an analysis of the impact of these drivers on the design of land administration systems, and particularly the cadastral component, which results in the broader land administration and narrower cadastral environment from which new systems

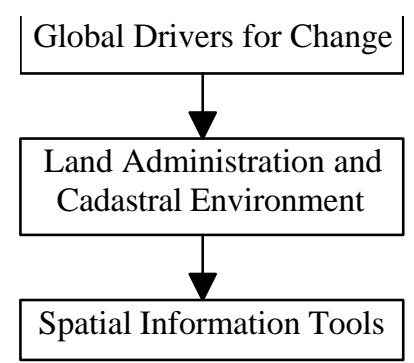

Figure 3. Hierarchy of Perspectives 
must evolve. This in turn identifies implementation issues with a focus on technical and administrative tools, which support these trends and developments, such as spatial data infrastructures and the Internet. All the changes proposed by the Bathurst Declaration can be categorised into these perspectives. The hierarchy of perspectives is shown in Figure 3. This hierarchy is expanded in the framework for re-engineering land administration systems in Figure 4 [Williamson \& Ting, 1999].

In the framework in Figure 4, global drivers impact on the whole social system, which comprises the re-engineering process. The framework shows that through a strategic planning process (including the use of rigorous case study methodologies), the vision of a new humankind-land relationship, together with the existing land administration system, results in the development of a conceptual land administration system. Through an implementation process, an operational land administration system is developed. Through benchmarking and feedback, the vision and conceptual system will be continually refined. Some of the key strategic planning and implementation issues within the reengineering process which are currently being researched by the author and his colleagues include the needs of evolving spatial decision support systems and SDIs, the impact of satellite positioning technologies on future SDIs, the spatial dimension of native title, the changing nature of spatial data infrastructures, understanding the business-infrastructure relationship in spatial information management, the use of the WWW and benchmarking processes for land administration systems (see http://www.sli.unimelb.edu.au/research/SDI_research/). 


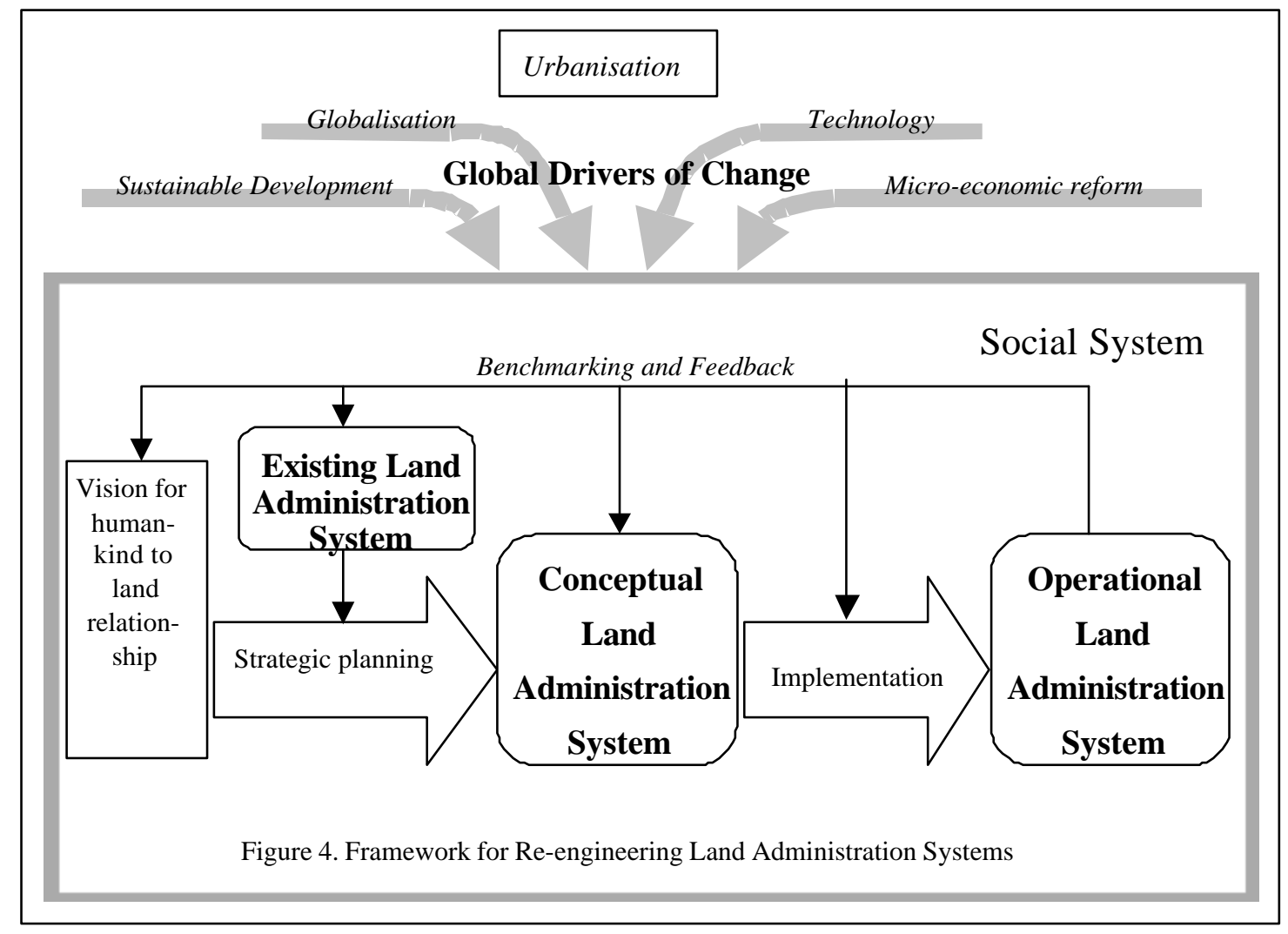

Two of the key steps in the re-engineering process, being the determination of the vision for the humankind-land relationship and the resulting conceptual land administration system, are discussed below.

\section{$\{$ heading 1$\}$ Need for a national land administration vision}

The development of a land administration vision for a country is an essential component of any re-engineering process. Land administration reform by its very nature is long term and as such there is a need for a clear road map to ensure that all developments and changes contribute to the overall vision for the land administration system for the country. Due to the complexity of land administration systems there is a strong argument for such projects to comprise "bite size" sub-projects which have a clear focus and often focus on administering one category of humankind to land (ie, individual private rights), 
however it is desirable that these sub-projects are undertaken as part of an agreed vision and global land administration strategy for the country.

Over the years a number of land administration or cadastral models or visions have been developed. Two of the most notable are described in the FIG Statement on the Cadastre [FIG, 1995] and the joint UN-FIG Bogor Declaration on Cadastral Reform [UN-FIG, 1996]. Cadastre is defined in the Statement on the Cadastre as:

“... normally a parcel based and up-to-date land information system containing a record of interests in land (e.g. rights, restrictions and responsibilities). It usually includes a geometric description of land parcels linked to other records describing the nature of the interests, and ownership or control of those interests, and often the value of the parcel and its improvements. It may be established for fiscal purposes (e.g. valuation and equitable taxation), legal purposes (conveyancing), to assist in the management of land and land use (e.g. for planning and other administrative purposes), and enables sustainable development and environmental protection."

The Bogor Declaration on Cadastral Reform expanded this definition to state that future cadastres would:

“...develop modern cadastral infrastructures that facilitate efficient land and property markets, protect the land rights of all, and support long term sustainable development and land management." And to “...facilitate the planning and development of national cadastral infrastructures so that they may fully service the escalating needs of greatly increased urban populations. These will result from the rapid expansion of cities that is already taking place and which is projected to continue into the 21 st century."

These visions, as well as the Bathurst Declaration, incorporated the concept of cadastral systems as infrastructures and highlighted the role of cadastres in the operation of land markets. While the Statement on the Cadastre was in reality a definition, the Bogor 
Declaration was more concerned with strategic and implementation issues, albeit in a relatively narrow cadastral sense.

Williamson [1996] developed a 10-year land information management vision for the State of Victoria, Australia to be a central component of any future land administration system. It built on his involvement with the development of the Statement on the Cadastre and the Bogor Declaration in addition to it receiving valuable input from many colleagues worldwide. This vision took a more information systems view of modern land administration and cadastral systems as follows:

"Simply within ten years all tiers of government, the private sector and the wider public will have controlled access to a standardised, complete, nation-wide, current, on-line land information system in real time, which is efficient, economically justified and compatible with other information systems."

A more recent investigation of future cadastral systems is the FIG Cadastre 2014 vision [Kaufmann, 1998; Kaufmann \& Steudler, 1998]. This was commissioned in 1994 by one of the Working Groups of Commission 7 (Cadastre and Land Management) as a 20-year vision. The final report was the result of a four-year process involving input from many countries worldwide. Cadastre 2014 recognises the changing relationship of humankind to land, the changing role of governments in society, the impact of technology on cadastral reform, the changing role of surveyors in society and the growing role of the private sector in the operation of the cadastre. Cadastre 2014 has made a valuable contribution to the understanding of future cadastral systems. However it did by design restrict its focus to cadastral systems and emphasised technological changes.

These examples of land administration visions show a trend for future land administration and particularly cadastral systems to take a broader and more integrated view than in the past. It is highly desirable that the components of land registration, cadastral surveying and mapping, planning and land valuation, and their role in the operation of land markets, should be considered as one integrated system where the common objective is sustainable 
development. A result of taking such a broad integrated approach is that all rights, restrictions and responsibilities, often overlapping (including both 2 dimensional and 3dimensional interests), relating to land, should be considered in designing and managing a land administration system, as shown schematically in Figure 5.

A key outcome of this review is the importance of a state or national spatial data infrastructure (SDI) as a key component of a land administration infrastructure. In developing an appropriate SDI such issues as the relationship between business users and the infrastructure, the relationship between spatial decision support systems and the SDI, the role of evolving communications technologies (Internet II, WAP, etc.), the changing roles of positioning technologies and their impact on the design of SDIs, the institutional requirements of SDIs and the identification of both private and public rights within the SDI, need to be considered [Williamson \& Ting, 1999].

Importantly the above approach includes many more interests than would traditionally be recorded in a cadastral or land registration system. This results in the multi-purpose cadastral concept which has been promoted for the last couple of decades but is only becoming a reality in recent times [McLaughlin, 1975; Panel on a Multi-purpose Cadastre, 1983]. Another outcome is the way that land administration is being viewed as an infrastructure to support sustainable development.

While these visions generally accept that there should be a range of different types of property rights maintained in a land administration system, such as private and public rights, common property, and leasehold, state and forestry interests, the visions require more detailed implementation strategies to be useful for specific countries. 


\section{Boundaries of:}

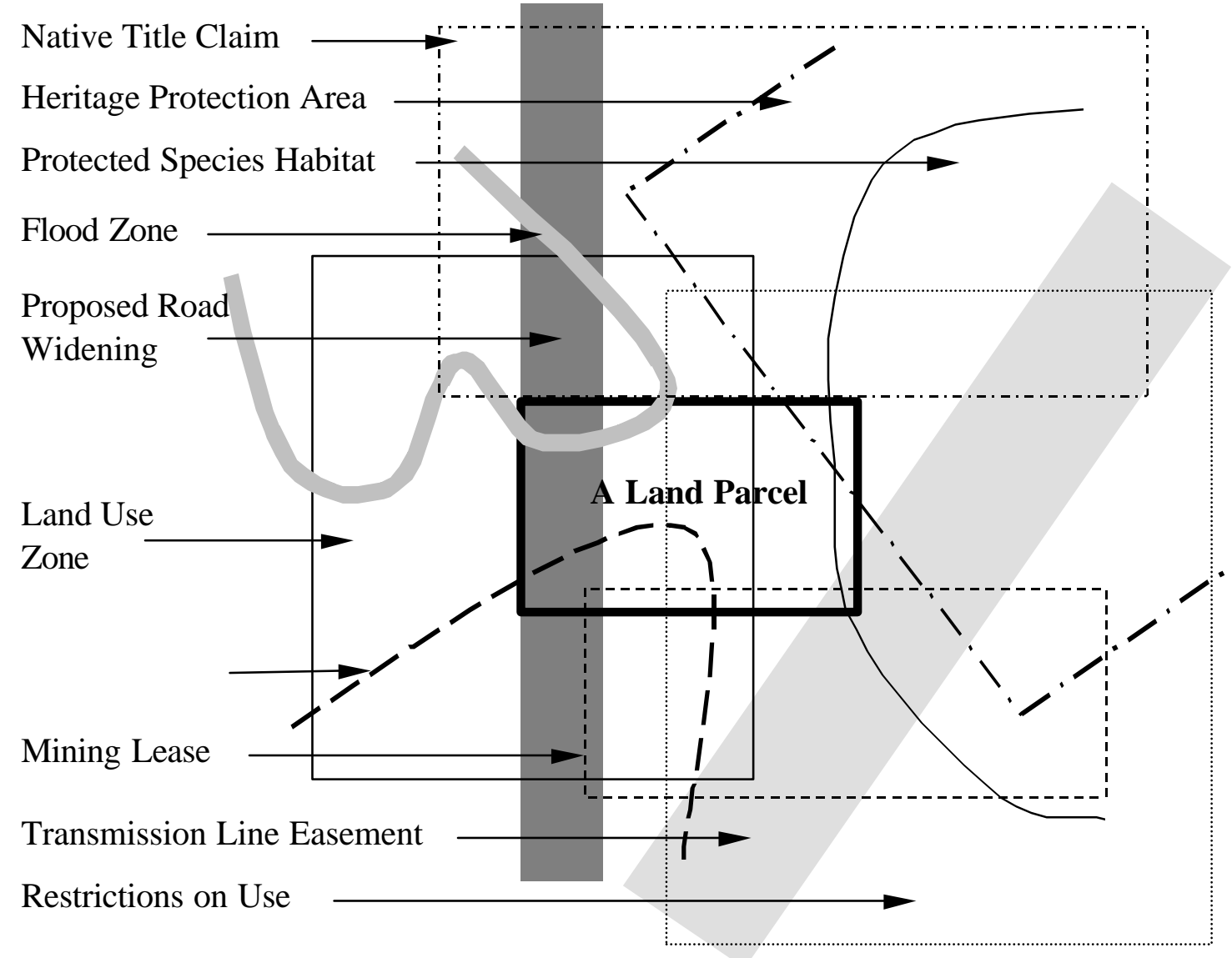

Figure 5: Schematic of overlapping rights, restrictions and responsibilities in a modern multi-purpose cadastre

\section{$\{$ heading 1$\}$ Implentation strategies}

In undertaking land administration reform it is important to consider the factors that drive or affect the reform and the choice of the specific strategies adopted. These factors are many and varied which re-enforces the statement that the land administration system for each country requires its own individual strategy. On the other hand strategies can be developed using the "tool box" approach. That is each specific strategy and resulting system can be made up of many separate, well-understood, generally proven and widely 
accepted components. For example systematic land titling may be an appropriate tool when individual private rights are well established, forms of communal tenures may be a more appropriate tool in formalising informal settlements or leasehold tenures many be a more appropriate tool in many rural areas [Williamson, 2000].

In designing a strategy, firstly it is important to recognise that almost every country will require a range of different strategies or tools depending on the relationship of humankind to land in each specific region in the specific country. In simple terms these arrangements include:

- Cities and urban areas, where active land markets operate on titled land or it is desirable that they operate;

- Cities and urban areas, occupied by informal settlements (squatter, illegal or low cost systems outside the formal or regulatory structures);

- High value agricultural lands which are titled and are part of the formal land market;

- Private untitled lands in cities, villages and rural areas where there is well established individual private ownership;

- Informal or illegal settlements in rural areas, especially in government forests,

- Lands which are subject to indigenous rights;

- Lands in all categories which are the subject of claims from previously dispossessed persons; and

- Government or state lands, reserves and forests and usually many other forms of common property.

To some degree these categories are common to all developing (and many developed) countries.

The second consideration is that the relationship of humankind to land is dynamic with the result that there is an evolution in the each of these categories. None of these relationships stay the same in the long term. They are affected by the impact of the global drivers on the relationship of humankind to land such as sustainable development, 
urbanisation, globalisation, economic reform and environmental management, as discussed above. As a result a different land administration response is required for each area or situation, within an overall national vision or strategy.

Third, the stage of development of the specific country has a major impact on the appropriate form of land administration response, and what is considered "best practice" for the individual country [Williamson, 2000]. As an example, in simple terms in the Asian-Pacific area there are four general categories of countries:

- Developed countries, such as Japan, Korea, Australia, New Zealand and Singapore;

- Newly industrialised countries or countries in transition, such as Peoples Republic of China, Indonesia, Thailand, Malaysia and the Philippines;

- Countries at an early stage of development such as Vietnam, Cambodia and Laos; and - Island states such as Fiji, Tonga and Vanuatu.

While each country has different development priorities, those in each group do share some similar priorities. A complication is that many countries do not fit easily into these categories with some countries having aspects of all categories. But in general the stage of development overall of an individual country does significantly influence the choice of which land administration strategies or tools are adopted.

The combination of all these factors determine or at least strongly influence, the specific strategy or strategies adopted in reforming or establishing the land administration system. These strategies draw on the land administration "tool box" for their institutional, legal, technical and administrative solutions.

For example there is a whole range of surveying and mapping technologies and approaches depending on what is the stage of development of the country and what is the major relationship of humankind to land which is being surveyed or mapped. These options include sporadic and systematic approaches, graphical and mathematical surveys, different positioning technologies such as satellite positioning or scaling off photomaps, 
different mapping technologies such as photomaps, topographic mapping and simple cadastral maps. The development of an appropriate national or state spatial data infrastructure is the key to developing an appropriate land administration infrastructure, which can support these different strategies and technologies.

In addition there is a range of options for the recording or determination of land tenure relationships. There are government guaranteed land titles, deeds registration systems, title insurance systems, qualified titles (both to boundaries and title), individual ownership, leasehold and communal or customary tenures.

For all these arrangements there are a range of technologies which are again strongly influenced by the wealth and development of the country. For example whether titles or deeds and cadastral maps will be computerised or held as paper records or whether the Internet can be utilised to access land records.

Institutional arrangements are influenced by the same factors. Whether the system is decentralised, deconcentrated or centralised.

The level of education and training in a country is a major influencing factor. For example if a country such as Indonesia wished to have a land administration system supported by a land title and cadastral surveying system similar to Australia, this could possibly require 40,000 professional land surveyors and 30 or more university programs educating professional surveyors [based on Steudler et al,1997]. Clearly this is not realistic in the short to medium term and as a result this re-enforces the need to develop appropriate solutions matched to the stage of development and specific requirements of the individual country.

Recognising all these constraints, Williamson [2000] argues there are a range of "best practices" or "tools" that are useful in undertaking the establishment or re-engineering of land administration systems under the headings of: 
- Land policy principles;

- Land tenure principles;

- Land administration and cadastral principles;

- Institutional principles;

- Spatial data infrastructure principles;

- Technical principles; and

- Human resource development principles.

\section{\{heading 1\} Conclusion}

This paper examines issues in re-engineering land administration systems to better meet future needs of society. The need for a vision, which incorporates sustainable development objectives and is based on a broader and more integrated approach, is argued. In order for countries or jurisdictions to work towards such a vision, a model for re-engineering land administration systems is discussed and a broad implementation strategy proposed.

The paper builds on the premise that the relationship between humankind and land in almost all societies is dynamic and influenced by global drivers, and that this dynamic relationship results in evolving land administration relationships. It also accepts that there is an increasing need for more complex and sophisticated decision-making world wide as a result of the sharpening tensions between human behavior and their worsening impact on the environment.

The paper then argues that most land administration projects undertaken by such organisations as the World Bank, have primarily focussed to date (almost by necessity) on issues of access to land, security of tenure and the operation of land markets. They have not usually considered the establishment of a wider national land administration infrastructure unless as a response to these narrower objectives. Their focus has primarily been economic as requested by the recipient countries. 
While international and national environmental and sustainable development policies sometimes mention the importance of land and land administration in implementing their policies, mention is at best very limited. The result is that current land administration systems are still structured around a 19th Century economic or land market paradigm and support the implementation of sustainable development objectives poorly, at best. As a result the paper calls for land administration systems to be re-engineered to better meet sustainable development objectives.

The importance of a clear national land administration vision is highlighted as is the need for a more detailed national land administration infrastructure which is able to serve the many different humankind to land relationships found in all countries.

The proposed implementation strategy has tried to highlight the complexity and interdependency of issues in land administration, cadastral systems and spatial information management. The strategy also highlights the multi-disciplinary nature of land administration systems. The paper has endeavored to show that any land administration strategy at any level of government must take a broader approach than in the past by recognising a wide range of social, economic and land related issues. A key outcome of such strategies is the development of appropriate national land administration infrastructures and spatial information management strategies conceived within a broad comprehensive vision.

The development of these strategies requires an understanding of the relationship between the changing humankind-land relationship, land administration policies, land administration systems, spatial business systems and spatial data infrastructures, while recognising the impact of technology across these dimensions (Figure 6). In this context, spatial data infrastructures will need

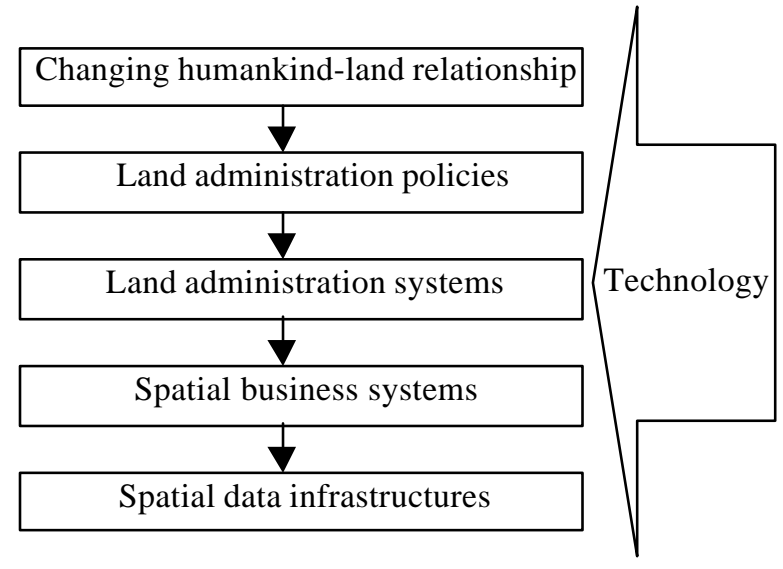

Figure 6. Developing land administration and spatial information management strategies 
to evolve to accommodate the business needs of land administration decision support systems and multi-purpose cadastres. An emphasis on business needs as distinct from infrastructure needs of spatial information will see a re-engineering of current SDIs as key components of future land administration systems.

In summary, the paper proposes that sustainable development will be the focus for the land administration responses to the changing humankind-land relationship in the foreseeable future. This will demand sophisticated land administration infrastructures in order to support the necessary decision-making. These in turn will require support from more generic information technologies integrated with spatial information technologies that can process and package data that is of sufficient quality, accuracy, relevance and inter-operability to the decision-makers. Herein lies the challenge that needs to be tackled in developing the next generation of land administration systems.

\section{\{heading 1\} Acknowledgements}

The author acknowledges that this paper has drawn heavily on papers by Williamson [2000], Williamson \& Ting [2000] and Williamson et al [1999]. The author also gratefully acknowledge the support of the Department of Geodesy, Delft University of Technology, The World Bank, Land Victoria (LV) of the Victorian Government and the Australian Research Council (ARC) (Grant C49930403) in supporting the research mentioned in the paper. The author also acknowledges the assistance provided by his colleagues at the Spatial Data Infrastructure and Cadastral Research Group, Department of Geomatics, the University of Melbourne in the preparation of the paper http://www.geom.unimelb.edu.au/research/SDI_research/. However, the views expressed in the paper are those of the author and do not necessarily reflect the views of supporting organisations.

\section{\{heading 1\}References}


Deininger, K. \& H. Binswanger, 1999. The evolution of the World Bank's Land Policy: principles, experience, and future challenges. World Bank Research Observer 14(2): 247276.

FIG, 1995. Statement on the Cadastre. International Federation of Surveyors. http://www.fig7.org.uk/cadastre/statement_on_cadastre.html (accessed 5 September 1999).

Galal, A. \& O. Razzaz, 2000. Reforming land and real estate markets. Internal publication. World Bank, Washington, DC.

Kaufmann, J., 1998. 'Cadastre 2014' - Report of Commission 7 Working Group 7.1, Modern cadastres. Proceedings, Commission 7, FIG XXI FIG Congress, Brighton, 20-24 July 1998. http://www.fig7.org.uk/Brighton98/proceedings.html (accessed 5 September 1999).

Kaufmann, J. \& D. Steudler, 1998. Cadastre 2014: A vision for a future cadastral system (Rheinfall, Switzerland: FIG.) http://www.swisstopo.ch/figwg71/Docs/Cad2014index.htm (accessed 5 September 1999).

McLaughlin, J.D., 1975. Design, development and implementation of the multi-purpose cadastre. PhD thesis. University of Wisconsin-Madison, U.S.A.

Panel on a Multipurpose Cadastre, 1983. Procedures and Standards for a Multipurpose Cadastre. National Academy Press, Washington, DC, 173p.

Steudler, D., I.P. Williamson, J. Kaufmann \& D.M. Grant, 1997. Benchmarking cadastral systems. The Australian Surveyor 42(3): 87-106.

Ting, L. \& I. Williamson, 1999. Cadastral trends: a synthesis. The Australian Surveyor 4(1): 46-54. (http://www.sli.unimelb.edu.au/research/publications/IPW_publ.html) 
UN-FIG, 1996. Bogor Declaration on Cadastral Reform.

http://www.sli.unimelb.edu.au/fig7/Bogor/BogorDeclaration.html (accessed on 30 July 1999).

UN-FIG, 1999. Bathurst Declaration on Land Administration for Sustainable Development. Workshop and UN-FIG International Conference on Cadastral Infrastructures for Sustainable Development, Bathurst and Melbourne, 25-27 October1999. http://www.sli.unimelb.edu.au/UNConf99/proceedings.htm.

United Nations Organization, 1992. Agenda 21. United Nations Division for Sustainable Development. 15 June 1992. http://www.un.org/esa/sustdev/agenda21text.htm

United Nations, 1999. Global Environment Outlook 2000. UN Environment Program. http://www.unep.org/unep/eia/geo2000/

World Bank, 1989. The World Bank Development Report. Oxford University Press, New York, NY.

World Bank, 2000. Toward an environmental strategy for the World Bank Group. Progress Report and Discussion Draft. World Bank, Washington, DC, April 2000. http://www.worldbank.org/environment/strategy/index.shtml (accessed 26 October 2000).

Williamson, I.P., 1991. Land information management at the World Bank. The Australian Surveyor 35(5): 41-51.

Williamson, I.P., 1996. A land information vision for Victoria. Report for Geographic Policy and Coordination, Victoria.

http://www.sli.unimelb.edu.au/research/publications/IPW_publ.html (accessed on 22 August 1999). 
Williamson, I.P., 2000. Land administration systems in developing countries.

Proceedings, International Conference on Land Policy Reform, Jakarta, 26 July 2000. http://www.landpolicy.org/ (accessed 25 October 2000).

Williamson, I.P. \& L. Ting, 1999. Land administration and cadastral trends: a framework for re-engineering. Proceedings, UN-FIG International Conference on Land Tenure and Cadastral Infrastructures for Sustainable Development, Melbourne, Australia: 317-338. http://www.geomi.unimelb.edu.au/UNConf99/proceedings.htm

Williamson, I.P., L. Ting \& D.M. Grant, 1999. The evolving role of land administration in support of sustainable development. The Australian Surveyor 44(20): 126-135.

Williamson, I.P. \& L. Ting, 2000. Land administration and cadastral trends - a framework for re-engineering. Computers, Environment and Urban Systems (in press), Elsevier, 25p. 


\section{University Library}

\section{- M M I N E R VA A gateway to Melbourne's research publications}

Minerva Access is the Institutional Repository of The University of Melbourne

Author/s:

Williamson, lan P.

Title:

Re-engineering land administration systems for sustainable development: from rhetoric to reality

Date:

2001

Citation:

Williamson, I. P. (2001). Re-engineering land administration systems for sustainable development: from rhetoric to reality, International Journal of Applied Earth Observation and Geoinformation, 3(3), 278-289.

Publication Status:

Published

Persistent Link:

http://hdl.handle.net/11343/33981 